\title{
"Company characteristics and risk management disclosure: empirical study of manufacturing companies listed on the Indonesia stock exchange"
}

\begin{tabular}{|c|c|}
\hline \multirow{2}{*}{ AUTHORS } & $\begin{array}{l}\text { Bambang Bemby Soebyakto } \\
\text { Mukhtaruddin (D http://orcid.org/0000-0003-2743-8080 }\end{array}$ \\
\hline & $\begin{array}{l}\text { Relasari } \\
\text { Alfianto Sinulingga }\end{array}$ \\
\hline ARTICLE INFO & $\begin{array}{l}\text { Bambang Bemby Soebyakto, Mukhtaruddin, Relasari and Alfianto Sinulingga } \\
\text { (2018). Company characteristics and risk management disclosure: empirical } \\
\text { study of manufacturing companies listed on the Indonesia stock exchange. } \\
\text { Problems and Perspectives in Management, 16(2), 396-411. } \\
\text { doi:10.21511/ppm.16(2).2018.36 }\end{array}$ \\
\hline DOI & http://dx.doi.org/10.21511/ppm.16(2).2018.36 \\
\hline RELEASED ON & Thursday, 21 June 2018 \\
\hline RECEIVED ON & Friday, 09 February 2018 \\
\hline \multirow[t]{2}{*}{ ACCEPTED ON } & Friday, 01 June 2018 \\
\hline & $(\mathrm{cc})$ EY-NC \\
\hline LICENSE & $\begin{array}{l}\text { This work is licensed under a Creative Commons Attribution-NonCommercial } 4.0 \\
\text { International License }\end{array}$ \\
\hline JOURNAL & "Problems and Perspectives in Management" \\
\hline ISSN PRINT & $1727-7051$ \\
\hline ISSN ONLINE & $1810-5467$ \\
\hline PUBLISHER & LLC "Consulting Publishing Company "Business Perspectives" \\
\hline FOUNDER & LLC "Consulting Publishing Company "Business Perspectives" \\
\hline
\end{tabular}

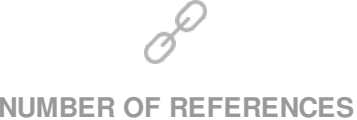

35
NUMBER OF FIGURES

1
NUMBER OF TABLES

6

(c) The author(s) 2022. This publication is an open access article. 


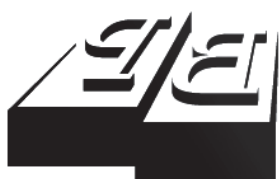

BUSINESS PERSPECTIVES

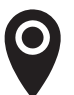

LLC "CPC "Business Perspectives" Hryhorii Skovoroda lane, 10, Sumy, 40022, Ukraine

www.businessperspectives.org

Received on: $9^{\text {th }}$ of February, 2018 Accepted on: $1^{\text {st }}$ of June, 2018
(C) Bambang Bemby Soebyakto, Mukhtaruddin, Relasari, Alfianto Sinulingga, 2018

Bambang Bemby Soebyakto, Ph.D in Economics Development, Faculty of Economics, Universitas Sriwijaya, Palembang, Indonesia.

Mukhtaruddin, Doctoral Program in Financial Management, Faculty of Economics, Universitas Sriwijaya, Palembang, Indonesia.

Relasari, Doctoral Program in Economics Development, Faculty of Economics, Universitas Sriwijaya, Palembang, Indonesia.

Alfianto Sinulingga, Bachelor Degree in Accounting, Faculty of Economics, Universitas Sriwijaya, Palembang, Indonesia.

\section{(ㄷ)(1) $(8)$}

This is an Open Access article, distributed under the terms of the Creative Commons Attribution-NonCommercial 4.0 International license, which permits re-use, distribution, and reproduction, provided the materials aren't used for commercial purposes and the original work is properly cited.
Bambang Bemby Soebyakto (Indonesia), Mukhtaruddin (Indonesia),

Relasari (Indonesia), Alfianto Sinulingga (Indonesia)

COMPANY CHARACTERISTICS AND RISK MANAGEMENT DISCLOSURE: EMPIRICAL STUDY OF MANUFACTURING COMPANIES LISTED ON THE INDONESIA STOCK EXCHANGE

\begin{abstract}
This research aims to obtain empirical evidence on the effect of company characteritics on risk management disclosure (RMD) from the annual reports of manufacturing companies. The sample consists of manufacturing companies listed on the Indonesia Stock Exchange (IDX) during the period 2010-2012. The total sample included 72 companies with three years observation and the examined firms reached 216. Results indicate that independent variables (firm size, profitability, leverage, public ownership, management ownership, and business complexity) have a significant effect on RMD. However, the hypotheses test with partial t-test indicate different results. Firm size (FS) and management ownership (MO) have significant effects, whereas leverage (LEV) has a negative and significant effect on RMD. Other variables, namely profitability (PRO), public ownership (PO), and business complexity (BC), have no significant effect on RMD.
\end{abstract}

\section{Keywords}

management disclosure, firm characteristics, firm size, return on asset (ROE), leverage, public ownership, management ownership and complexity

\section{JEL Classification G32, L22}

\section{INTRODUCTION}

In conducting business and operational activities, the company requires funds in every economic activity it executes in order to ensure its sustainability in the future (Jones et al., 2017). At the beginning of its development, a company basically operates by focusing on just one specific business. However, with the development of business caused by globalization, as well as technological development and innovation, that company is eventually required to evolve and further develop its business. To keep pace with such development, which is a result of the more competitive and complex global economic conditions, the company requires substantial funds so that it can achieve its organizational goals. On the one hand, having limited funds to finance operations restricts every unit of company activity, thus prompting the company to source out funds from external parties, such as investors or creditors.

On the other hand, investors and creditors who have excess funds want to invest their funds in the hope of gaining profit and interest from the company. In doing so, the investor deals with the prospect of a "high risk, high return" investment, which means that the greater the returns expected, the greater the risks attached to it (Ong \& $\mathrm{Ng}$, 2018). On the contrary, the smaller the profit expected, the smaller the 
risks involved in the investment. On the basis of this concept, investors have paid more attention to the inherent risks involved in their potential investments in order to arrive at the best investment decision. To analyze the amount of risks and profits they can obtain, investors may use various means to examine their options, one of which is by analyzing the company's financial statement. In Indonesia, this document essentially describes a company's financial condition by processing accounting data in accordance with the accepted accounting standard in the country. Thus, investors can analyze how much risks they have and the benefits they may expect in each investment to be made on a company's annual financial statements.

This case is different from the revealed case of accounting scandals committed by multinational firms like Enron, Xerox, Green Tree, and WorldCom, which involved financial statements prepared by public accountant firms. These cases shocked the world because of the level of manipulation involved to make the companies look well operated based on their doctored financial statements, even though the reality reflects the opposite situation. These cases have had a major impact on investors and creditors who have invested in these companies. Such cases also damaged public trust on the completeness, accountability, and reliability of these financial statements, especially the investors and financial statement users, who considered these documents unreliable decision-making tools (Anisa, 2012). Such a perception was exacerbated by the financial crisis that hit the global economy in the period 2007-2008.

Such cases highlight the assumption that financial statements are only structured to conform to the accounting standards and do not actually reflect the circumstances and reality of a company as a whole. In addition, investors have also raised issues regarding the transparency of companies in terms of reporting their operational activities to relevant third parties. Almilia and Retrinasari (2007) stated that a company is expected to be open and transparent in disclosing its financial information so that stakeholders, such as investors and creditors, are assisted in the decision-making process, especially when situations constantly change and economies face uncertainties. This reality has encouraged many parties to ask companies to extend the disclosure of the company's operations in the annual report.

One of the most important things that must be disclosed in the annual report is a company's operational activities. Investors would want to know how far the company has managed the risks within the company. Companies are required to overcome, reduce, or eliminate existing risks. This is because investors expect their investments to generate profit and not lead to losses. Hence, investors require companies to disclose positive and negative information about events occurring within the company. By disclosing the company's risk management (RM), the investors can make informed decisions related to their investments.

RMD is a hot issue that has gained research interest since 1998, when the Institute of Chartered Accountants in England and Wales (ICAEW) - the institute of accountants based in England and Wales - published a discussion paper entitled "Financial Reporting of Risk - Proposal for a Statement of Business Risk". The publication recommended that all companies must report the company's business risk disclosure information in its annual report to assist stakeholders in the decision-making process (Linsley \& Shrives, 2006).

Owing to the importance of RMD, government policy makers in other countries, such as Indonesia, began to formulate, create, and issue policies and regulations that require companies to disclose risk information in their respective annual reports. One example is the Indonesian Accounting Standard Number 60 (2012) about Financial Instruments. This document states that companies must prepare annual reports that can help potential investors evaluate the types and levels of risks arising from their financial instruments. The document also encourages companies to disclose their risk management efforts in their financial statements so that such information can assist the stakeholders in their decision-making efforts. 
Another regulation to disclose risk is the Decree of the Chairman of Capital Market Supervisory and Financial Institution Number 134/BL/2006, which deals with the Obligation of Submission of Annual Reports for Issuers and Public Companies, through which issuers are required to include the company's risks and the efforts made to address those risks in the annual reports.

The increasing demand for company disclosure has also led many researchers to examine this phenomenon. Common corporate disclosure practices include corporate social responsibility (CSR), good corporate governance (GCG), intellectual capital disclosure, and RMD. Among these, however, RMD is the least-researched topic among researchers in Indonesia, even though the issue of RM has been widely discussed and has attracted the interest of various parties related to the company.

Thus far, RMD has been studied in various countries. One study (Linsley \& Shrives, 2006) examined company annual reports in the United Kingdom and found a significant relationship between FS and natural risk level with the extent of RMD. Another research abroad (Chandiramani, 2009) concluded that share price has a significant impact on the quality of risk disclosure exposure among companies listed on the Dutch Stock Exchange, whereas PRO and leverage have no effect on the quality of RMD. In contrast, Rajab and Schachler (2009) conducted research in Great Britain and found a significant positive relationship between dual-listed companies (i.e., listed on the UK and US Stock Exchanges) and risk-sharing in industries with risk disclosure, whereas no significant relationship exists between FS and leverage and the RMD level.

Meanwhile, in Indonesia, RMD has not been widely studied unlike CSR disclosure, GCG, and other types of social disclosure. Among the few works devoted to RMD, one study (Taures, 2011) examined the non-financial companies listed on IDX and found that the firm characteristics simultaneously have a significant effect on RMD. That study also found that only FS and industry types have significant effects on RMD, whereas product and geographical diversification, leverage, and PRO have no significant correlation to RMD. Another study (Fathimiyah et al., 2012) conducted a survey of the banking industry in IDX and found that the MO and ownership of domestic institutions do not have a significant positive relationship with RMD, whereas the variable of PO and the ownership of foreign institutions do not have a significant negative correlation to RMD. Meanwhile, another study (Andarini \& Januarti, 2010) examined RMD and found that FS has a significant positive relationship with the existence of RM committee and the separation of the RM committee. Meanwhile, other variables like independent commissioner, board size, auditor reputation, $\mathrm{BC}$, financial reporting risk, and leverage have no significant correlation with the existence of RM comittee and the separation of the RM comittee.

A study that examined risk disclosure (Anisa, 2012) found that leverage and FS are positively correlated with corporate RMD, whereas industry type, PRO, and PO structure have no significant effect on RMD. Other results in this study indicate that the most disclosed type of risk in the annual reports of non-financial companies listed on the IDX is their financial risk.

Owing to the varied research results on RMD and the increasing demand of investors and other parties with regards RMD, research on RM has become a very interesting topic worthy of further study in Indonesia. One study (Anisa, 2012) took samples from manufacturing companies listed on the IDX; that study was able to provide a more specific and realistic picture (Anisa, 2012) by taking a sample of all non-financial companies listed on the IDX. This study intends to determine the effect of firm characteristics on RMD. The characteristics of the company are those that distinguish it from other companies, and include FS, ownership, leverage, $\mathrm{PRO}$, type of industry, BC, product and geographical diversification, and others.

The current research aims to examine the effect of firm characteristics (i.e., FS, PRO, leverage, PO, MO, and $\mathrm{BC}$ ) on RMD. This research excludes industry type variables, because the study only includes a 
single type of industry: manufacturing sector. In addition, other company characteristics, namely, FS, $\mathrm{PRO}$, leverage, and PO, are re-tested to obtain more specific results. The difference is that the measurements made to the above variables, among others, aim to measure the PRO. Here, we use return on equity (ROE) to calculate the net profit margin based on a company's ability to generate profits, which is measured by comparing returns earned by companies using their own capital. Another difference is in the measurement of FS. In past studies, FS was measured by using the natural logarithm of total assets, whereas in this study, the FS was first measured by sorting the total assets of all sample companies and then dividing it into three groups of companies: small, medium and large size.

In addition, the current research uses $\mathrm{MO}$ and $\mathrm{BC}$ as independent variables. The addition of $\mathrm{MO}$ aims to determine whether it has an effect on RMD. A previous research (Fathimiyah et al., 2012) found that the higher $\mathrm{MO}$, the greater the company's RM, because they hold a position as the company's shareholder. Hence, good RM results in their conditional ownership. Meanwhile, we re-tested the selection of BC, because, according to a past study (Andarini \& Januarti, 2010), BC was measured by the number of business segments owned by the company, which showed insignificant results on disclosure of RM committee and the separation of the RM committee. This assumption encouraged the researchers to add the two abovementioned variables in the current study.

\section{LITERATURE REVIEW}

\subsection{Stakeholder theory}

Stakeholder theory states that a company is not an entity that operates only for the interests of the entity itself; rather, it must be able to provide benefits to its stakeholders, which means that the existence of an entity is strongly affected by the stakeholders of the company (Rokhmawati et al., 2017; Rokhmawati \& Gunardi, 2017). The term "stakeholders" refers to the groups concerned about the existence or activities of the company and have an influence on the company. Stakeholder theory can be divided into two: primary stakeholders and secondary stakeholders. The "primary stakeholders" are a group of entities who, without the company, cannot survive and continue operations; these include shareholders, investors, employees, consumers, suppliers, and governments. The "secondary stakeholders" are those who influence the company or are affected by the company and include the mass media and the wider community; however, they are not related to the company's transactions and are not essential to their sustainability. From both types of stakeholders, the most influential group in the company's operations consists of the primary stakeholders.

According to the above explanation, the influence of the stakeholders is so important, such that the company must maintain its relationships with stakeholders by accommodating their requests, such as by supplying the information they need in aid of decision making. One example of such information is RMD. By including RMD in the company's annual report, this demonstrates that the company aims to satisfy the stakeholders by supplying the right information that they need (Andarini \& Januarti, 2010).

\subsection{Agency theory}

According to a past study by Jensen and Meckling (1976), the term "agency relations" refers to an agreement whereby the principal gives the right to another person to run the company's operations. In this theory, the principal is the owner of the company, including the shareholders, creditors and so on, whereas the agent who is given the right to manage the company is the company's management. In the company operations, the principal provides facilities and funds to ensure the sustainability of the company, whereas the agent is given the right to manage such facilities and funds in order to provide benefits for the principal. To repay the hard work of the agent, the principal shall grant bonuses, salary increases, better compensations, and promotions (Anisa, 2012).

As the theory suggests, the above conditions will benefit both parties in the company's operations. However, in reality, the agent often commits a breach with a contract previously approved by both parties, 
in which the agent is responsible for the principal's welfare. In fact, the agent often has self-interest in this agreement by trying to achieve prosperity as much as possible by utilizing every sacrifice from the other party, which is the principal company. This scenario often leads to agency conflict, which is a conflict between the principal and the agent.

Such conflicts can be minimized and solved by the management, as the agent, by organizing and operating the company in a way that benefits the interests of the principal. In addition, the principal can oversee the company's operations to determine whether the agent, or the management in this case, runs the company in accordance with its goals and interests.

\subsection{Risk management}

In overcoming the impact of risks that could obstruct a company's operations, the management should minimize, manage, and address such risks. In this way, the management can respond to the needs of the parties by identifying the actual risks, the risks to be overcome by the management itself, the risks that can be handled by others, and the ways to deal with the risks within the company (Taures, 2011). For this reason, companies must be able to manage existing risks by performing RM.

Smith (1995) defined RM as the process of identifying, measuring, and financing control of a risk that threatens the assets and income of a company or project and can cause damage or loss to the company. Djojosoedarso (2003) mentioned that a framework is needed to manage risk; this framework involves the following steps: (1) identifying or determining the objectives to be achieved through RM; (2) identifying the possibility of loss occurrence or risk identification; (3) evaluating and measuring the magnitude of potential losses, which refers to the magnitude of the opportunity occurring within a certain period and the magnitude of the consequences of the losses, and the ability to predict the extent of obvious loss; (4) seeking the best or most appropriate way or combination of ways to solve problems arising from the occurrence of a loss; (5) coordinating and implementing decisions that have been taken to mitigate risks; and (6) administering, monitoring, and evaluating all the steps and strategies that have been taken to handle risks.
Several methods are available to overcome the risks that a company could face and is already facing. According to Darmawi (2010), the benefits of RM are as follows: (1) RM may prevent failure for the company; (2) RM directly supports the increase of profit; (3) RM can provide indirect profit; (4) RM may promote the presence of a stable mind for managers due to the protection against pure risk, which is a non-material property of the company; and (5) RM protects firms from pure risk, and because creditors, customers, and suppliers prefer a well-protected company, they can indirectly help improve the company's public image.

RM is obviously useful for any company. According to Linsley and Shrives (2006), RM is used by firms to manage existing risks or seize opportunities related to company objectives.

\subsection{Risk management disclosure}

Companies conduct risk management to cope with and minimize any existing risks. Any countermeasures employed will certainly be beneficial when companies report them to the parties concerned. In this regard, RMD is an important part of corporate reporting and disclosure. The media is often used to report and disclose company operations, among others, through financial reports and annual reports. Through such disclosure, concerned parties will know the condition of the company's operations. The information is well-disclosed if the company can deliver the information to its stakeholders properly. With RMD, the information of risk management is well-disclosed when users of the annual report are informed of the opportunities, prospects, dangers, losses, threats, and exposure that will affect the company today and in the future (Linsley \& Shrives, 2006).

Riahi-Belkaoui (2004) stated that the objectives of disclosure are to (1) describe the acknowledged and provide relevant measurements of factors beyond the measurement used in financial statements, (2) describe the acknowledged and present the benefits of things, (3) provide information that will help investors and creditors assess the potential risks of recognized and unrecognized things, (4) provide important information that enables users to make comparisons within a year and among several years, (5) provide information 
on future cash inflows and outflows, and (6) assist investors in assessing the return on their investment.

According to those objectives, we now know the importance of disclosing the information needed by stakeholders in annual reports, including RMD. Disclosures are presented in annual reports as part of the company's responsibility to its stakeholders. In the end, trust is established between the management as the agents and its stakeholders as the principal.

Driven by the importance of RMD, the public policies in Indonesia and other countries have started to regulate RMD as applied in practice. In 1997, Malaysia launched a regulation called The Financial Reporting Act, which requires listed companies on Bursa Malaysia to include reports about internal control conditions, control risk, and RM in their annual reports. In 1993, Great Britain launched a regulation about company disclosure through Operating and Financial Review, which required listed companies to present a risk review. In 1998, the Combined Code on Corporate Governance stated that the UK Stock Exchange must require listed companies to manage their internal control system and describe how the system works, establish internal RM procedures, and report risks.

In Indonesia, standard and policy makers have started to pay close attention to risk disclosure. According to current regulations, standards, and policies, risk disclosure benefits companies internally and externally.

\subsection{Company characteristics}

\subsubsection{Firm size}

FS is the parameter used to determine whether companies are large, medium, or small. FS could be measured from the assets owned by the firm. A large pool of assets indicates a large FS, whereas a limited pool of assets equates to a small FS. FS is affected by the depth of the disclosure of the financial and nonfinancial information owned by companies (Ghani et al., 2018). Large companies tend to have varied interests in external parties. Thus, large companies engage in wide information disclosure. Considering FS, users are likely to be more interested in the information held by large companies than in that offered by small companies. Information disclosure is widely demanded to aid the decision making of stakeholders.

Generally, large companies tend to disclose information more actively than small companies do. According to Anisa (2012), FS exerts a positive significant effect on RM. In line with the work of Anisa (2012), other research, such as the research of Anggraini (2006), Sembiring (2005), Susilatri et al. (2011), and Gunardi et al. (2016), found that FS is the most consistent variable in CSR disclosure. Other studies (Andarini \& Januarti, 2010) found that the FS has a positive significant effect on RMD. The first hypothesis is formulated accordingly, i.e., FS significantly affects RMD.

\subsubsection{Profitability}

PRO is the ability of a company to produce income with every available resource from the company's operation (Widyaningsih et al., 2017). A high income provides a positive measurement of the management's capability of operating the company on behalf of its stakeholders (Asmeri et al., 2017). PRO is measured using several methods, including net profit margin, return on asset (ROA), return on investment, return on equity (ROE), and other measurement methods. ROE is used to measure the level of return obtained by investors from their investment.

According to previous research, PRO leads to different outcomes. Anisa (2012) found that PRO has no significant correlation with RM. Other research (Taures, 2011), in line with the research of Anisa (2012), reported that PRO has no significant effect on the risk disclosure of companies. Other studies on disclosure presented the same results (Anggraini, 2006). Sembiring (2005) stated that PRO has no effect on CSR disclosure.

These inconsistent results drive researchers to re-examine the effects of PRO on the risk disclosure of companies in their annual reports. PRO shows company performance and thus allows leaders to manage their risks effectively. PRO also reduces the risk disclosure level because of good company performance. When the level of profita- 
bility is low, companies will disclose risk information actively, because low PRO indicates high risks for companies. The second hypothesis is formulated accordingly, i.e., PRO significantly affects RMD.

\subsubsection{Financial leverage}

Companies tend to finance their activities by relying on lending, which is reflected on their financial leverage. LEV is one of the financial parameters that measure how a company performs in fulfilling their long-term needs. According to Anisa (2012), LEV is measured by the debt-to-asset ratio and thus exerts a positive and significant effect on RMD. Debt-toasset ratio indicates the size of the company's liability which is used to finance assets within the company's operations. A high debt-to-asset ratio equates to the great dependence of the company on external parties, such as creditors. With a high debt-to-asset ratio, companies are likely to face difficulties in making payments for their liabilities and interests.

According to stakeholder theory, a company should be able to broadly disclose its condition to stakeholders. Thus, in terms of risk disclosure, a company is expected to disclose its risks actively. Similarly, a high leverage level indicates that the company will disclose their RM, because when the liability level is high, the creditor will urge the company to RMD. The third hypothesis is formulated accordingly, i.e., LEV significantly affects RMD.

\subsubsection{Public ownership}

Company ownership can be divided into two categories: internal ownership, which is ownership by management; and external ownership, which is ownership by institutional investors, society, etc. $\mathrm{PO}$ is the number of shares owned by the public relative to the total shares outstanding in the market. With great PO, the company is controlled not only by internal parties and stakeholders, but also by the public, and this control influences the company's operation and decision making.

PO affects a company's policy and operation, especially the disclosure of financial statements or annual reports (Gunardi et al., 2016). This effect is due to the public having ownership of that company, in which case it has the power to affect other parties, such as mass media and communities by giving comments and feedback. PO certainly urges companies to publish annual reports in a timely manner and engage in wide information disclosure for the interest of the public that holds shares in the company. The fourth hypothesis is formulated accordingly, i.e., PO significantly affects RMD.

\subsubsection{Management ownership}

In the structure of a company's ownership, the management is given the right to participate in capitalization to carry out the company's operation continuously. Management, in this case, acts as the owner of the company as well. It not only runs the company, but also takes control of the company's operations and daily activities that can be profitable for them and their shareholders.

According to stakeholder theory, the smaller the $\mathrm{MO}$, the higher the interest conflict will be between management and the owner. By contrast, the greater the $\mathrm{MO}$, the greater the struggle of the management in asserting their rights as the principal without ignoring their responsibility as the agent of the company.

Obviously, a great $\mathrm{MO}$ boosts the performance of the management in overcoming the risks to their capital. The greater their ownership, the greater their decision-making power and possibility of risks. Under great risks, the management as the owner and manager of the company will intend to disclose their RM to ensure that their investment will not be affected by those risks. The fifth hypothesis is thus formulated accordingly, i.e., MO significantly affects RMD.

\subsubsection{Business complexity}

In running their operations, companies cannot strictly rely on one BS, as they are likely to expand to other BS to increase funding. If the company relies on only one BS, it will not have the opportunity to earn profit from other segments. Therefore, many companies develop innovation in every BS.

Generally, BC can be seen from the amount of BS owned by the company. Every BS certainly involves opportunities and risks, and the greater the complexity, the higher the risks. Andarini and Januarti (2010) showed that a high complexity can increase risks in different levels, including risks 


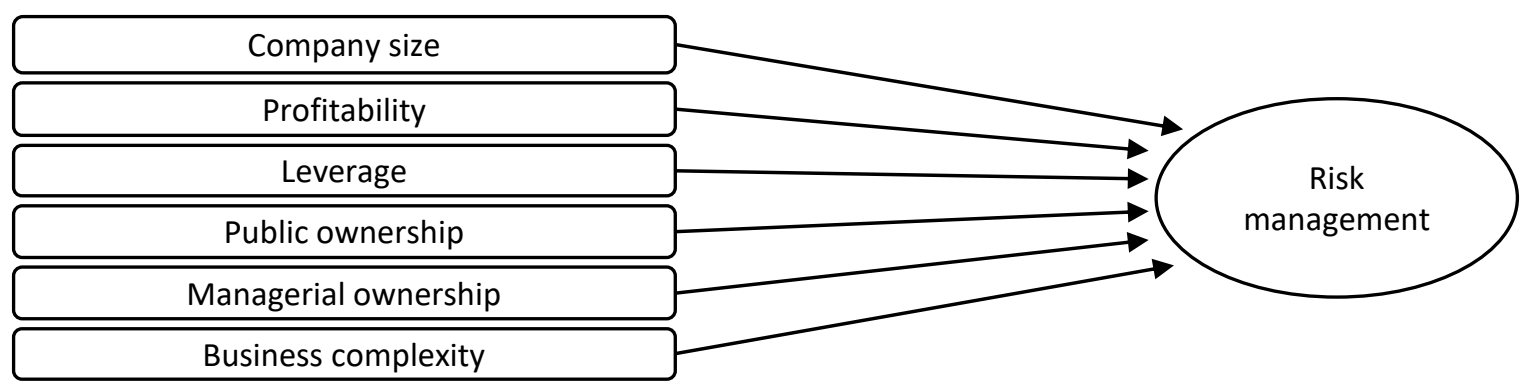

Figure 1. Conceptual framework

in the operation and technology sector, in which case risk control mechanisms should be employed. These mechanisms should be well managed to overcome the risks effectively. Every risk arising from the $\mathrm{BC}$ of the company will prompt annual report users to ask the company to actively engage in RMD. The sixth hypothesis is formulated accordingly, i.e., BC significantly affects RMD.

According to the analysis of the theoretical framework and previous research that tested the factors affecting RMD, we establish this study's theoretical framework as follows.

\section{METHODS}

\subsection{Population and sample}

The population of this research comprises manufacturing companies listed on the IDX in the period 2010-2012. The study period spans three years in accordance with the recommendations of previous studies. Purposive sampling is used as the sampling technique to select the sample according to certain criteria for research purposes. The sampling criteria in this research are as follows: (1) companies that published annual reports for the period 2010-2012 in www.idx.co.id and/or in their official websites; (2) companies that reported income and zero losses in the period 2010-2012; and (3) financial statements measured in rupiah. On the basis of these criteria, 72 companies are selected as the sample.

\subsection{Definition of operational and variable measurement}

The RMD types disclosed in annual reports are divided into six groups. Every RMD is valued as 1; if the company does not engage in RMD, the value is set to 0 . The types of RMD available in the company are grouped in the following table.

Table 1. Grouping of risk management disclosure types

\begin{tabular}{|c|c|c|}
\hline No. & Types of RMD & Definition \\
\hline 1 & Financial risk & A risk related to company's finances \\
\hline 2 & Operation risk & $\begin{array}{l}\text { A risk caused by insufficiency or } \\
\text { malfunction of internal processes, } \\
\text { human errors, system failures, or } \\
\text { external problems that affected the } \\
\text { company's operations }\end{array}$ \\
\hline 3 & Power risk & $\begin{array}{l}\text { A risk resulting from the abuse of } \\
\text { authority }\end{array}$ \\
\hline 4 & $\begin{array}{l}\text { Technological } \\
\text { and information. } \\
\text { Processing risk }\end{array}$ & $\begin{array}{l}\text { A risk caused by the lack of access } \\
\text { to technology and information } \\
\text { processing }\end{array}$ \\
\hline 5 & Integrity risk & $\begin{array}{l}\text { A risk caused by the inconsistency of } \\
\text { employees and manager in fulfilling } \\
\text { the company's purpose }\end{array}$ \\
\hline 6 & Strategy risk & $\begin{array}{l}\text { A risk caused by errors in formulating } \\
\text { strategies for the achievement of } \\
\text { corporate objectives }\end{array}$ \\
\hline
\end{tabular}

The grouping of risks according to type is aimed at knowing how many sentences pertaining to risk disclosure are presented by the companies in their annual reports. The sentences presented as basis for coding are more reliable than other analysis units (Anisa, 2012). Calculations are performed in the current research to determine the RMD levels in annual reports by using the percentage of disclosure, such as the following formulation:

$$
R M D=\frac{\sum \text { Risk disclosure }}{\sum \text { Risk }} \cdot 100 \%,
$$

where $R M D$ - risk management disclosure, $\sum$ Risk disclosure - total company risk management disclosure, and $\sum$ Risk - total risk. 
In this research, limitations are used to identify company risk disclosure. Linsley and Shrives (2006) suggested a number of limitations in company risk disclosure: (1) risk can be defined as good, bad, and uncertain; (2) sentences are considered to be pertaining to risk disclosure if the users of the company report are given information about opportunities or prospects or about risks, dangers, and losses that are likely to affect the company in the future; (3) disclosure must be explicitly declared and not simply signed/implied; (4) repeated disclosures are noted as risk disclosure sentences every time they are discussed; and (5) if a disclosure is too vague to be identified, then, it will not be considered as a risk disclosure.

FS refers to the size of companies as measured by the total assets that they own. Based on this definition, the manufacturing companies in the sample are classified into three groups, namely, small, medium, and big companies, which have corresponding values of 1,2 , and 3 , respectively, as summarized in Table 2.

Table 2. Grouping of firms based on FS

\begin{tabular}{c:c:c}
\hline No & Size & Value \\
\hline $1-25$ & Big & 3 \\
\hline $26-49$ & Medium & 2 \\
\hline $50-73$ & Small & 1 \\
\hline
\end{tabular}

The profitability of a firm can be measured by using several metrics, including ROE, LEV, $P O$, $M O$, and $B C$. ROE refers to the firm's utilization of its capital to generate profit and is calculated as follows:

$$
R O E=\frac{E A T_{x t}}{\sum E q u i t y} .
$$

$L E V$ is measured as follows by dividing total liabilities by total assets:

$$
L E V=\frac{T D_{x t}}{\sum \text { Asset }_{x t}} .
$$

$P O$ is computed as:

$$
P O=\frac{\sum \text { Public stock }}{\sum \text { Company stock }} \cdot 100 \%,
$$

while $M O$ is formulated as:

$$
M O=\frac{\sum \text { Management ownership }}{\sum \text { Company stock }} \cdot 100 \% \text {. }
$$

$B C$ is measured as follows by calculating the natural logarithm and amount of business segments owned by a company:

$$
B C=\ln \sum B S .
$$

\subsection{Method of data analysis}

The collected data are then calculated and processed to check whether the proposed hypotheses can be supported or rejected. The following multiple linear regression model is used for the data analysis:

$$
\begin{aligned}
& R M D=\alpha+\beta F S+\beta P R O+\beta L E V+ \\
& +\beta P O+\beta M O+\beta B C+\varepsilon .
\end{aligned}
$$

\section{RESULTS}

\begin{tabular}{|c|c|c|c|c|c|c|}
\hline \multicolumn{7}{|c|}{ Coefficientsa } \\
\hline & \multirow{2}{*}{$\underset{\text { B }}{\text { Model }}$} & \multicolumn{2}{|c|}{$\begin{array}{c}\text { Unstandardized } \\
\text { coefficients }\end{array}$} & \multirow[t]{2}{*}{$\begin{array}{l}\text { Standardized } \\
\text { coefficients }\end{array}$} & \multirow[t]{2}{*}{$\mathbf{t}$} & \multirow[t]{2}{*}{ Sig. } \\
\hline & & Std. error & Beta & & & \\
\hline \multirow{7}{*}{1} & (Constant) & .301 & .049 & - & 6.126 & .000 \\
\hline & FS & .103 & .018 & .386 & 5.672 & .000 \\
\hline & PRO & .022 & .063 & .023 & .352 & .725 \\
\hline & LEV & -.195 & .075 & -.161 & -2.595 & .010 \\
\hline & $\mathrm{PO}$ & .178 & .092 & .133 & 1.928 & .055 \\
\hline & $\mathrm{MO}$ & .675 & .277 & .165 & 2.437 & .016 \\
\hline & $\mathrm{BC}$ & .008 & .027 & .023 & .315 & .753 \\
\hline
\end{tabular}

\subsection{Multiple regression analysis}

Multiple regressions are performed to test the proposed hypotheses. The results are summarized in the following table.

Table 3. Results of multiple regressions

Source: Secondary data processed through SPSS 16, output SPSS.

Note: a. Dependent variable: $R M D$. 
Based on the above table, the multiple linear regression model is rewritten as follows:

$$
\begin{aligned}
& R M D=0.301+0.103 F S+0.22 P R O- \\
& -0.195 L E V+0.178 P O+0.756 M O+ \\
& +0.008 B C .
\end{aligned}
$$

\subsection{Determination coefficient test $\left(R^{2}\right)$}

The results of the determination coefficient test for the manufacturing companies listed on IDX during the period 2010-2012 are summarized below.

Table 4. Result of the determination coefficient test $\left(R^{2}\right)$

\begin{tabular}{c|c|c|c|c} 
& \multicolumn{4}{c}{ Source: Secondary data processed by SPSS 16, output SPSS. } \\
\hline Model & $\mathbf{R}$ & $\mathbf{R 2}$ & $\begin{array}{c}\text { Adjusted } \\
\mathbf{R 2}\end{array}$ & Std. error \\
\hline 1 & $.475 a$ & .225 & .203 & .1954481 \\
\hline
\end{tabular}

Note: Predictors: (Constant), BC, PRO, LEV, MO, FS, PO.

The companies in the sample have an adjusted $R^{2}$ value of 0.203 , which indicates that the proposed multiple linear regression model can explain $20.3 \%$ of the influence of the independent variables (e.g., $F S, P R O, L E V, P O, M O$, and $B C$ ) on $R M D$, while the other $79.7 \%$ is explaned by other factors not covered in this research.

\subsection{Simultaneous test (F-test)}

The effects of company characteristics on $R M D$ are then investigated by conducting an $F$-test. The

\begin{tabular}{|c|c|c|c|c|c|c|}
\hline & Model & $\begin{array}{l}\text { Sum of } \\
\text { squares }\end{array}$ & Df & $\begin{array}{l}\text { Mean } \\
\text { square }\end{array}$ & $\mathbf{F}$ & Sig. \\
\hline \multirow{3}{*}{1} & Regression & 2.320 & 6 & .387 & 10.123 & $.000 a$ \\
\hline & Residual & 7.984 & 209 & .038 & & \\
\hline & Total & 10.304 & 215 & & & \\
\hline
\end{tabular}
results are summarized in Table 5.

Table 5. Results of the F-test

Notes: a. Predictors: (Constant), BC, PRO, LEV, MO, FS, PO. b. Dependent variable: $R M D$.

The F-test yields a value of 10.123 with a significance level of 0.000 , which is less than 0.05 . Therefore, the proposed multiple linear regression model can be used to predict RMD. Moreover, FS, $P R O, L E V, P O, M O$, and $B C$ all show simultaneous and significant effects on $R M D$.

\subsection{Partial test (t-test)}

A $t$-test is performed to test the significance of the effects of the independent variables (e.g., FS, $P R O$, $P O, M O$, and $B C$ ) on the $R M D$ of manufacturing companies listed on IDX during the period 20102012. The results are summarized in the following table.

\begin{tabular}{|c|c|c|c|c|c|c|}
\hline & \multirow{2}{*}{ Model } & \multicolumn{2}{|c|}{$\begin{array}{c}\text { Unstandardized } \\
\text { coefficients }\end{array}$} & \multirow{2}{*}{$\begin{array}{l}\text { Standardized } \\
\text { coefficients } \\
\text { Beta }\end{array}$} & \multirow{2}{*}{$\mathbf{T}$} & \multirow{2}{*}{ Sig. } \\
\hline & & B & $\begin{array}{c}\text { Std. } \\
\text { error }\end{array}$ & & & \\
\hline \multirow{7}{*}{1} & (Constant) & .301 & .049 & - & 6.126 & 000 \\
\hline & FS & .103 & .018 & .386 & 5.672 & 000 \\
\hline & PRO & .022 & .063 & .023 & .352 & .725 \\
\hline & LEV & -.195 & .075 & -.161 & -2.595 & 010 \\
\hline & $\mathrm{PO}$ & .178 & .092 & .133 & 1.928 & .055 \\
\hline & $\mathrm{MO}$ & .675 & .277 & .165 & 2.437 & .016 \\
\hline & $B C$ & .008 & .027 & .023 & .315 & .753 \\
\hline
\end{tabular}

Table 6. Results of the $t$-test

Source: Secondary data processed by SPSS 16, output SPSS.

Note: a. Dependent variable: $R M D$.

The following conclusions can be drawn from the results presented above:

1. The effect of $F S$ on $R M D$ has a $t$ score of 6.126 and a $\beta$ score of 0.103 , the significance of which 0.000 is less than 0.05 . In other words, FS has a positive and significant effect on $R M D$ at the $5 \%$ significance level, thereby supporting $H 1$.

2. The effect of $R O E$ on $R M D$ has a $t$ score of 5.672 and a $\beta$ score of 0.022 , the significance of which 0.725 is greater than 0.05 . In this case, $R O E$ does not have a significant effect on $R M D$, thereby rejecting $H 2$.

3. The effect of $L E V$ on $R M D$ has a $t$ score of -2.595 and a $\beta$ score of -0.195 , the significance of which 0.010 is less than 0.05 . Therefore, $L E V$ has a significant negative effect on the $R M D$ of manufacturing firms listed on IDX during the period 2010-2012, thereby supporting H3.

4. The effect of $P O$ on $R M D$ has a $t$ score of 1.928 and a $\beta$ score of 0.178 , the significance of which 0.55 is greater than 0.05 . In this case, $P O$ does not have a significant effect on $R M D$, thereby rejecting $H 4$. 
5. The effect of $M O$ on $R M D$ has a $t$ score of 2.437 and a $\beta$ score of 0.675 , the significance of which 0.016 is greater than 0.05 . In other words, $M O$ has a significant positive effect on $R M D$, thereby supporting $H 5$.

6. The effect of $B C$ on $R M D$ has a $t$ score of 0.315 and a $\beta$ score of 0.008 , the significance of which 0.753 is greater than 0.05 . Therefore, $B C$ does not have a significant effect on $R M D$, thereby rejecting $\mathrm{H} 6$.

\section{DISCUSSION}

\subsection{Firm size and risk management disclosure}

Consistent with the conclusions of Anisa (2012) and Taures (2011), both of which stated that a larger company has a higher level of $R M D$, the findings of this work highlight the positive and significant effect of FS on RMD. These results also coincide with those of Andarini and Januarti (2010) who found that large companies have higher levels of disclosure than small companies. Meanwhile, Taures (2011) showed that large companies generally engage in $B C$ activities that affect their shareholders, public, and surroundings. Therefore, these companies must also disclose additional information in their annual reports due to the diverse interests of their stakeholders. Larger companies are also faced with a higher level of risk. Therefore, to satisfy the demands of their stakeholders, these companies must employ effective $R M$ practices to prevent such risk from adversely affecting their operations and then disclose risk management-related information in their annual reports.

Mujiyono and Nany (2010) supported the argument of Taures (2011) by stating that larger companies have a higher tendency to disclose more information in their annual reports for several reasons. For instance, larger companies incur lower costs in producing and disclosing information, because having a low cost can motivate a company to disclose more information. Large companies usually have readily available information and can disclose such information broadly, thereby explaining their low information production cost. These companies also have a high tendency to provide heterogeneous products and promote geographic diversification by operating in other countries. Operating in various places and promoting product diversity can also encourage companies to disclose more information in order to satisfy the interests of their stakeholders in each of their products and operational areas. Large companies also tend to recruit highly skilled employees to facilitate the implementation of hightech management reporting systems, which can increase their disclosure of information. These companies also rely on information disclosure to maintain favorable relationships with their investors and stakeholders, as well as to benefit their operations.

The results of this study are also in line with agency theory, which posits that large companies have higher agency costs than small companies (Jensen \& Meckling, 1976). Given these high costs, large companies disclose information more broadly compared with small companies. Based on these findings, a larger $F S$ will greatly diversify the interests of stakeholders and subsequently increase their demand for disclosing more information in annual reports. To respond to this demand, companies have to engage in $R M D$.

\subsection{Profitability and risk management disclosure}

$P R O$ shows a positive yet insignificant effect on $R M D$. This finding opposes the arguments of agency theory, which states that a higher $P R O$ can encourage principal shareholders to buy additional shares from the company, increase the controlling power of external parties, and ultimately reduce the agency cost (Anisa, 2012). Linsley and Shrives (2006) found that those companies with a low $P R O$ tend to incur high risks and engage in less $R M D$ to divert the attention of their stakeholders from such risks. This result is in line with the findings of Anisa (2012) who stated that a low PRO prevents a company from conducting its operations smoothly and consequently increases its risks. Moreover, given that an increasing amount of risk is very difficult to manage, companies tend to engage in less $R M D$ when faced with a large amount or risks.

Budianto (2009) examined the information disclosure practices of companies and found that certain fundamental factors have no significant effects on information disclosure. By measuring profitabil- 
ity based on $R O A$, Budianto (2009) revealed that the relatively small $R O A$ of a company may be ascribed to its large investments in fixed assets and its lack of transparency in disclosing information in its annual reports. Meanwhile, Hardiningsih (2008) found that a high level of $P R O$ information is informative enough for stakeholders. Therefore, providing any additional information does not greatly influence their decisions.

Based on previous studies, data on the profitability of companies can provide accurate information to some stakeholders. After disclosing its profitability level, a company feels less urgency in disclosing other types of information. Similarly, those companies that engage in $R M D$ will be perceived by stakeholders as having a high return on capital and proficient $R M$. Therefore, the investors of these companies do not have a high demand for $R M$ information.

\subsection{Leverage and risk management disclosure}

Agency theory predicts that those companies with higher $L E V$ ratios will reveal more information, because these companies usually have higher costs (Jensen \& Meckling, 1976). Additional information must be released to dispel the doubts of bondholders regarding the fulfillment of their rights as creditors Yintayani (2011). However, the results of this study show that $L E V$ has a negative and significant effect on RMD. In other words, a lower $L E V$ corresponds to a higher $R M D$. These findings contradict the arguments of agency theory, which posits that a higher $L E V$ corresponds to a higher dependence of the company on outside parties, thereby increasing their chances of breaching large debt contracts.

Similar results are obtained by Yintayani (2011) who examined other disclosure practices, such as CSR disclosure. Specifically, Yintayani showed that having a higher $L E V$ increases the chances for a company to breach its debt contract (such as by increasing its earnings statement in its annual report) and reduces its chances of violating debt agreements. A debt contract not only contains the terms of interest coverage, working capital, and shareholder equity, but also stipulates that the company must maintain a certain level of $L E V$ (Watts \& Zimmerman, 1986). In this case, a company with a high level of $L E V$ has a high likelihood to vio- late its credit contract and report higher earnings in its annual report. To report higher profits, the management must reduce the costs of the company, including its costs for information disclosure (Belkaoui \& Karpik, 1989). A higher $L E V$ does not necessarily correspond to a higher disclosure to meet the information demands of long-term debitors because of the other mechanisms that the company employs to reduce its agency problems related to investors and creditors. These conditions also reduce the tendency for companies to engage in risk management practices, because they fear that disclosing and mitigating risks will draw the skepticism of their creditors. Specifically, these creditors may think that the company is too risky and that its risk mitigation practices will fail. These perceptions will subsequently introduce additional risks for the company, such as increasing the potential for stakeholders to lose or withdraw their capital from the company.

\subsection{Public ownership and risk management disclosure}

$P O$ has a positive yet insignificant influence on $R M D$, which is consistent with the findings of Anisa (2012), who found that the ownership structure of the sampled company is mostly controlled by domestic and foreign institutional ownership. In other words, $P O$ does not influence the making of $R M D$ related decisions, because the majority of the shareholders want to make profits from the company. In this case, by engaging in $R M D$, a company reveals its risk management competitiveness to its competitors, which may have detrimental consequences.

Haryanto and Aprilia (2008) obtained similar findings. They attributed the positive yet insignificant effect of $P O$ on $R M D$ to the fact that public investors are generally small investors who do not greatly influence the policies of a company, including its information disclosure. Haryanto and Aprilia (2008) also utilized a small sample that could not represent the entire population, thereby introducing biases into their findings.

Poulus (2011) ascribed such positive yet insignificant effect to the management's consideration of the costs and benefits that will be received by the company after disclosing certain information in its annual reports. Meanwhile, Claessens et al. (2000) 
found that the $P O$ system in Indonesia is primarily dominated by family ownership, which is also very common among the companies listed on IDX. La Porta et al. (1999) stated that Indonesia offers a low degree of legal protection to minority shareholders, thereby resulting in the poor disclosure of company-related information and concentrating the ownership of Indonesian firms to family shareholders, which in turn reduces the power of accounting information. In this case, family control can strongly influence the accounting information offered by the company to a very small circle of shareholders (i.e., the family controlling company).

Based on these findings, the positive yet insignificant effect of $P O$ on $R M D$ is likely caused by the high concentration of $I O$ and family ownership among Indonesian manufacturing firms, which consequently reduces the power of $P O$ in influencing the policies of a company. In line with this insignificant effect, disclosure level is also not affected by $P O$.

\subsection{Management ownership and risk management disclosure}

Management, such as boards of commissioners and directors, is not only limited to company managers, but also involves company owners. The operations of a company are highly dependent on management. Meanwhile, company owners may demand for more information to be included in the annual reports of their companies. In this regard, the management acts as both the writer and reader of annual reports.

These arguments are in line with agency theory, which posits that a higher $M O$ corresponds to a lower tendency for agency conflict to occur because the management is also interested in the operations of the company. Specifically, the management wants to know the extent of $R M$ and is held accountable for the $R M$ decisions made by the company as disclosed in its annual report (Fathimiyah et al., 2012).

Companies often resort to information disclosure to control the conflicts among their shareholders, creditors, other interested parties, and management. Therefore, information disclosure is closely associated with the relationships between the manager and owner, as well as between the owner (through the manager) and creditor. With a broader level of information disclosure, the management can reduce the possibility for such conflicts to occur, which in turn will increase the cost of oversight within the company.

Based on the statement above, a higher level of $M O$ will encourage the company to improve its performance and overcome the risks that threaten its capital. A higher level of ownership corresponds to a higher power over the decisions made by management and consequentially increases the potential for risks to occur. When faced with a great amount of risks, the management, as the owner and manager of the company, will engage in $R M D$ to protect the investments of shareholders from such risks.

In sum, the decision-making role of the management has a crucial in the operations of a company. The management determines all policies related to the sustainability of the firm. In this case, companies must also disclose the performance of their management in their annual reports. Therefore, a higher level of $M O$ corresponds to a higher level of $R M D$ disclosure in the annual report of the company.

\subsection{Business complexity and risk management disclosure}

The results also highlight a positive yet insignificant effect of $B C$ on $R M D$, which echoes the findings of Taures (2011). The positive correlation obtained is consistent with the proposed hypothesis but has no significant relationship. The insignificance of such effect may be ascribed to the product diversification strategy, which is adopted by the company to address the high amount of risks associated with product failure. Therefore, before expanding its operations, a company must carefully analyze the needs of its customers, the quality of its products, and other aspects related to the expansion. These activities are especially important when the company fails within a single $B S$. Given that such failure will likely increase the amount of risks they are facing, some companies attempt to maintain the loyalty of their stakeholders by disclosing less information about the performance of their management. 
Other studies reveal the positive yet insignificant effect of $B C$ on $R M D$ (Andarini \& Januarti, 2010). Such insignificant yet positive relationship may be explained by the fact that $B C$ is measured based on the number of $B S$ owned by the firm. However, Subramaniam et al. (2009) argued that using the number of $B S$ as a proxy measurement of $B C$ is inappropriate, because such number does not reflect the complexity of a company's business activities and operations. Those companies with few $B S$ or only a major area BS tend to have a wider geographical BS. Moreover, a company with only one $B S$, but having geographical segments and op- erational areas in hundreds of areas, tends to engage in a more complex business compared with those companies with many $B S$ yet few geographical segments.

In sum, using the number of $B S$ to measure $B C$ cannot accurately reflect the extent of $R M$ being undertaken by a company. The increasing complexity of a business will likely introduce more risks for the company, and the management is responsible for disclosing the extent of risk management within each $B S$ and geographical segment of the company.

\section{CONCLUSION}

This research tests the effects of several company characteristics, such as FS, $P R O, L E V, P O, M O$, and $B C$, on the RMD of manufacturing companies listed on IDX during the period 2010-2012. The following conclusions can be drawn from the findings:

1) FS, $P R O, L E V, P O, M O$, and $B C$ simultaneously affect $R M D$;

2) FS and $M O$ have a significant and positive effect on $R M D, L E V$ has a significant and negative effect, and the other variables $(P R O, P O$, and $B C$ ) have positive yet insignificant effects;

3) financial management risk is the most cited $R M$ practice in annual reports, while technology and information risk is the least cited;

4) the proposed multiple linear regression model can explain $20.3 \%$ of the influence of the independent variables (i.e., $F S, P R O, L E V, P O, M O$, and $B C$ ) on $R M D$, while the other $79.7 \%$ can be explained by other factors not covered in this research.

The following suggestions are proposed based on these conclusions:

1. Future studies may include other company characteristics, such as $I O$ and existence of a $R M$ committee, as well as extend the period or timeline of their research to provide other researchers with an in-depth understanding of the factors that influence the $R M D$ of manufacturing companies listed on IDX.

2. The management must disclose all $R M D$-related activities of their companies in their annual reports.

3. In future studies, the contents of annual reports must be analyzed by more than one researcher to minimize the subjectivity problem that may arise from the measurement of $R M D$.

The following limitations of this work must be noted:

1. The data used in this research are limited to manufacturing companies. Therefore, the findings do not reflect the situation of the entire capital market (IDX).

2. $R M D$ is measured based on the quantity, rather than the quality, of disclosure. 
3. The adjusted $R^{2}$ score is $20.3 \%$, which means that $R M D$ may also be affected by $79.7 \%$ of the factors that are not covered in this research.

4. This research was only performed by one researcher, which may give rise to a subjectivity problem.

\section{REFERENCES}

1. Almilia, L. S., \& Retrinasari, I. (2007). Analisis Pengaruh Karakteristik Perusahaan terhadap Kelengkapan Pengungkapan dalam Laporan Tahunan Perusahaan Manufaktur yang Terdaftar di BEJ. In Proceeding Seminar Nasional Inovasi dalam Menghadapi Perubahan Lingkungan Bisnis.

2. Andarini, P., \& Januarti, I. (2010). Hubungan Karakteristik Dewan Komisaris dan Perusahaan terhadap Pengungkapan Risk Management Committee (RMC) pada Perusahaan Go Public Indonesia. In Simposium Nasional Akuntansi XIII. Purwokerto.

3. Anggraini, F. R. R. (2006). Pengungkapan Informasi Sosial dan Faktor-Faktor yang Mempengaruhi Pengungkapan Informasi Sosial dalam Laporan Keuangan Tahunan (Studi Empiris pada Perusahaan-Perusahaan yang terdaftar Bursa Efek Jakarta). In Simposium Nasional Akuntansi IX. Padang.

4. Anisa, W. G. (2012). Analisis Faktor yang Mempengaruhi Pengungkapan Manajemen Risiko (Studi Empiris pada Laporan Tahunan Perusahaan-perusahaan Nonkeuangan yang Terdaftar di BEI Tahun 2010). Universitas Diponegoro. Retrieved from http://eprints.undip.ac.id/35288/1/ Skripsi_05.pdf

5. Asmeri, R., Alvionita, T., \& Gunardi, A. (2017). CSR Disclosures in the Mining Industry: Empirical Evidence from Listed Mining Firms in Indonesia. Indonesian Journal of Sustainability Accounting and Management, 1(1), 16-22. http:// doi.org/10.28992/ijsam.vli1.23

6. Belkaoui, A., \& Karpik, P. G. (1989). Determinants of the Corporate Decision to Disclose
Social Information. Accounting,

Auditing \& Accountability

Journal, 2(1). http://doi. org/10.1108/09513578910132240

7. Budianto, A. S. (2009). Pengaruh Faktor-faktor Fundamental terhadap Kualitas Pengungkapan Sukarela dalam Laporan Tahunan pada Perusahaan Manufaktur yang Terdaftar di Bursa Efek Indonesia. Jurnal Akuntansi Kontemporer, 1(2), 123-142.

8. Chandiramani, G. (2009). Quality of Risk Reporting. Erasmus University.

9. Claessens, S., Djankov, S., \& Lang, L. H. P. (2000). The separation of ownership and control in East Asian Corporations. Journal of Financial Economics, 58(1-2), 81112. http://doi.org/10.1016/S0304405X(00)00067-2

10. Darmawi, H. (2010). Manajemen Risiko. Jakarta: Bumi Aksara.

11. Djojosoedarso, S. (2003). Prinsipprinsip Manajemen Risiko dan Asuransi. Jakarta: Salemba Empat.

12. Fathimiyah, V., Zulfikar, R., \& Fitriyani, F. (2012). Pengaruh Struktur Kepemilikan terhadap Risk Management Disclosure (Studi Survei Industri Perbankan yang Listing di Bursa Efek Indonesia Tahun 2008-2010). In Simposium Nasional Akuntansi XV. Banjarmasin.

13. Ghani, E. K., Jamal, J., Puspitasari, E., \& Gunardi, A. (2018). Factors Influencing Integrated Reporting Practices Among Malaysian Public Listed Real Property Companies: A Sustainable Development Effort. International Journal of Managerial and Financial Accounting, 10(2), 144-162. http://doi.org/10.1504/ IJMFA.2018.10012811

14. Gunardi, A., Febrian, E., \& Herwany, A. (2016). The implication of firm-specific characteristics on disclosure: the case of Indonesia. International Journal of Monetary Economics and Finance, 9(4), 379-387. http://doi. org/10.1504/IJMEF.2016.080080

15. Hardiningsih, P. (2008). Analisis Faktor-faktor yang Mempengaruhi Voluntary Disclosure Laporan Tahunan Perusahaan. Jurnal Bisnis Dan Ekonomi, 15(1), 67-79.

16. Haryanto, H., \& Aprilia, Lady (2008). Asosiasi antara Karakteristik Perusahaan dan Kualitas Pengungkapan Sukarela dalam Laporan Tahunan. Buletin Ekonomi Akuntansi Manajemen Dan Studi Pembangunan.

17. Jensen, M. C., \& Meckling, W. H. (1976). Theory of the firm: Managerial behavior, agency costs and ownership structure. Journal of Financial Economics, 3(4), 305 360. http://doi.org/10.1016/0304405X(76)90026-X

18. Jones, P., Wynn, M., Hillier, D., \& Comfort, D. (2017). The Sustainable Development Goals and Information and Communication Technologies. Indonesian Journal of Sustainability Accounting and Management, 1(1), 1-15. http://doi. org/10.28992/ijsam.v1i1.22

19. La Porta, R., Lopez-De-Silanes, F., \& Shleifer, A. (1999). Corporate ownership around the world. The Journal of Finance, 54(2), 471-517. http://doi.org/10.1111/00221082.00115

20. Linsley, P. M., \& Shrives, P. J. (2006). Risk Reporting: A Study of Risk Disclosures in the Annual Reports of UK Companies. The British Accounting Review, 38(4), 387-404. http://doi.org/10.1016/j. bar.2006.05.002

21. Mujiyono, M., \& Nany, M. (2010). Pengaruh Leverage, Saham Publik, Size dan Komite Audit terhadap 
Luas Pengungkapan Sukarela. Jurnal Dinamika Akuntansi, 2(2), 129-134.

22. Ong, T. S., \& Ng, P. S. (2018). The Effects of Share Repurchase Announcements on Returns in the Malaysia Stock Market. Indonesian Journal of Business Finance and Accounting, 1(1), 1-19.

23. Poulus, S. (2011). Pengaruh Umur Perusahaan, Ukuran Perusahaan, dan Porsi Kepemilikan Saham Publik terhadap Tingkat Pengungkapan Informasi Laporan Tahunan Perusahaan (Studi Pada 80 Emiten yang Tergabung dalam Indeks Kompas 100 Tahun 2008 di Bursa Efek Indonesia). Retrieved from http://repository.unpad. ac.id/9537/

24. Rajab, B., \& Schachler, M. H. (2009). Corporate Risk Disclosure by UK Firms: Trends and Determinants. World Review of Entrepreneurship, Management and Sustainable Development, 5(3), 224. http://doi.org/10.1504/ WREMSD.2009.026801

25. Riahi-Belkaoui, A. (2004). Accounting Theory. Cengage Learning EMEA.

26. Rokhmawati, A., \& Gunardi, A. (2017). Is going green good for profit? Empirical evidence from listed manufacturing firms in
Indonesia. International Journal of Energy Economics and Policy, 7(4), 181-192.

27. Rokhmawati, A., Gunardi, A., \& Rossi, M. (2017). How Powerful is Your Customers' Reaction to Carbon Performance? Linking Carbon and Firm Financial Performance. International Journal of Energy Economics and Policy, 7(6), 85-95.

28. Sembiring, E. R. (2005). Karakteristik Perusahaan dan Pengungkapan Tanggung Jawab Sosial: Study Empiris pada Perusahaan yang Tercatat di Bursa Efek Jakarta. In Simposium Nasional Akuntansi VIII. Solo.

29. Smith, C. W. (1995). Corporate Risk Management. The Journal of Derivatives, 2(4), 21-30. http://doi. org/10.3905/jod.1995.407920

30. Subramaniam, N., McManus, L., \& Zhang, J. (2009). Corporate Governance, Firm Characteristics and Risk Management Committee Formation in Australian Companies. Managerial Auditing Journal, 24(4), 316-339. http://doi. org/10.1108/02686900910948170

31. Susilatri, S., Agusti, R., \& Indriani, D. (2011). Pengaruh Leverage, Profitabilitas, Size, Umur Perusahaan dan Ukuran Dewan Komisaris terhadap
Pengungkapan Tanggung Jawab Sosial Perusahaan (Studi pada Perusahaan Pertambangan yang Listing di BEI Tahun 2004-2008). Jurnal Pekbis, 3(1), 421-428.

32. Taures, N. S. I. (2011). Analisis Hubungan antara Karakteristik Perusahaan dengan Pengungkapan Risiko (Studi Empiris pada Laporan Tahunan PerusahaanPerusahaan Nonkeuangan yang Terdaftar di BEI Tahun 2009). Universitas Diponegoro. Retrieved from http://eprints.undip. ac.id/28515/1/Skripsi10.pdf

33. Watts, R. L., \& Zimmerman, J. L. (1986). Positive Accounting Theory. Englewood Cliffs: Prentice Hall.

34. Widyaningsih, I. U., Gunardi, A., Rossi, M., \& Rahmawati, R. (2017). Expropriation by the Controlling Shareholders on Firm Value in the Context of Indonesia: Corporate Governance as Moderating Variable. International Journal of Managerial and Financial Accounting, 9(4), 322-337. http://doi.org/10.1504/IJMFA.2017.10009973

35. Yintayani, N. N. (2011). Faktorfaktor yang Memengaruhi Corporate Social Responsibility (Studi Empiris pada Perusahaan yang Terdaftar di Bursa Efek Indonesia Tahun 2009). Universitas Udayana. 